\title{
Study on Aircraft Noise Around Tribhuvan International Airport, Kathmandu, Nepal
}

\author{
Mohan K. Bhattarai ${ }^{1}$ and B.K.Sapkota ${ }^{2}$ \\ ${ }^{1}$ Central Department of Physics, University Campus, \\ Tribhuvan University, Kathmandu, Nepal \\ ${ }^{2}$ Institute of Engineering, Pulchowk Campus, Lalitpur, Nepal \\ e-mail: mohankbhattarai@yahoo.com
}

\begin{abstract}
Present work was carried out to collect primary data from the field with the help of noise meter and thus spatial and diurnal variation of background and aircraft noise level was analyzed. Seventeen sampling sites were chosen nearby Tribhuwan International Airport (TIA) and air route of aircraft flyover. Noise measurements were carried out under normal atmospheric environmental condition at temperature ranges from $25^{\circ} \mathrm{C}-30^{\circ} \mathrm{C}$ excluding rainy and windy days. Among the sampling sites, the Equivalent Continuous Noise Level $\left(\mathrm{L}_{\text {Aeq }}\right)$ of background noise measured maximum at Balkumari (73.2 dBA) and minimum at Datidol (49.2 dBA). Noise meter was allowed to record aircraft noise level when aircraft produced noise greater than background noise level and recorded until it reduced to background noise level. The maximum value of aircraft noise level, $\left(\mathrm{L}_{\text {Aeq }}\right)$ measured at Gothatar $(101.5 \mathrm{dBA})$ which lies north east from the TIA and at the same height as the airport ground and minimum at Datidol (63.5 dBA).To analyse the spatial variation of aircraft noise of different sampling sites, contour map was plotted with the help of origin software. The $\mathrm{L}_{\text {Aeq }}$ of more than 60 percent sampling sites fall under the severe noise exposure class $(\geq 75$ $\mathrm{dBA}$ ) which causes substantial hearing loss. Implementation of noise control measurement and public awareness are recommended to control adverse effect of noise pollution.
\end{abstract}

Key words: sound internsity level, noise pollution, adverse effect, awareness, control measures

\section{Introduction}

Tribhuvan International Airport (TIA) is the only one international airport of Nepal. It is the busiest transaction point which links various domestic airports of the country and international airport for other countries. Aircraft flyover has been impressively increasing every year in TIA which produces high level of noise pollution during landing and take-off which causes adverse health effect to the people nearby TIA in Kathmandu valley. TIA is mostly affected by the aircraft noise due to the frequent jet aircraft flyover. Thus the research to find out noise level produced by the aircraft flyover is a great issue to be safe from noise hazards. Spatial and diurnal variation should be analyzed to implement the control measures of noise pollution.
In Nepal major observation in noise pollution were made from 1985. Shrestha and Shrestha measured noise level at different congested areas of Kathmandu valley. The equivalent continuous noise levels $\left(\mathrm{L}_{\text {Aeq }}\right)$ ranged from $70 \mathrm{dBA}$ to $100 \mathrm{dBA}$ (Sapkota 2004). The indoor $\mathrm{L}_{\mathrm{Aeq}}$ in Balaju industrial areas and Himal cement factory in Kathmandu ranged from $70 \mathrm{dBA}$ to $100 \mathrm{dBA}$ (Miyoshi 1987). It is reported that noise levels of $80 \mathrm{dBA}$ to 100 dBA were typical for Kathmandu valley (Manandhar et al.1987). Regarding with this matter the research was conducted to find out the noise level in different areas in Kathmandu valley. The $\mathrm{L}_{\text {Aeq }}$ measured during heavy traffic area ranged from $65.1 \mathrm{dBA}$ to $74.5 \mathrm{dBA}$ and 63.2 dBA to $72.1 \mathrm{dBA}$ in low traffic area (Sapkota et al. 1997). A case study done in "Noise Pollution around the Netaji Subash Chandra Bose International 
Airport, Kolkata" reported the short $\mathrm{L}_{\text {Aeq }}$ from $66 \mathrm{dBA}$ to $95 \mathrm{dBA}$ during aircraft movement (Biswas 2002). Although some research have been done on vehicle noise and some indoor and outdoor noise pollution, the research in aircraft noise pollution is relatively rare in Nepal.

The investigation conducted among 6000 persons in London with different level of aircraft noise exposure has reported that depression, irritability, awakening and difficulty in falling asleep were significant in high noise exposure (Tornopolsky et al. 1980). WHO recommended that noise level greater than $75 \mathrm{dBA}$ can bring substantial hearing loss. It is suggested that to be able to hear and understand spoken messages in class room the noise level shouldn't exceed $35 \mathrm{dBA}$, which should be less than $55 \mathrm{dBA}$ for outdoor playground (Berglund \& Lindvall 1995).

\section{Methodology}

\section{Location of Tribhuvan International Airport (TIA)}

Tribhuvan International Airport (TIA) is located in Kathmandu valley. It is $5.56 \mathrm{~km}$ east of the capital city. Hills and mountains are just about $13 \mathrm{~km}$ away all around the airport. The history of TIA has been started since 1947 and it has got the status of international airport during 1964 . It is situated at $27^{\circ} 41^{\prime} 50^{\prime \prime}$ north latitude and $85^{\circ} 21^{\prime} 28$ "east longitude. Its runway dimension is $1000 \mathrm{ft} \times 150 \mathrm{ft}$. The runway surface strength is $54 \mathrm{~F} / \mathrm{A} / \mathrm{T}$ and Apron capacity is Int' 1-9 medium and wide body category aircraft, and Domestic - 15 small aircraft (CAAN 2004).

\section{Field survey and data collection}

The sites for the aircraft noise measurement were chosen by the field survey and also adopting the suggestions of engineering department of civil aviation authority so that 17 sampling sites were selected. Most of them lie on the way of incoming and outgoing routes of the aircraft flyovers. The measurements were carried out under the normal atmospheric environmental condition excluding rainfall and windy days during the months of May and June in 2007 between 9 am to $5 \mathrm{pm}$. Observations of the data were made at the time of landing and take off period of the aircrafts. The noise meter of the following specifications was used to measure the noise level:

Integrating sound level meter (Model NL-05, JIS C 1502, RION CO., LTD., TOKYO, JAPAN)

\section{Data analysis}

Aircraft noise is a fluctuating noise, so to get the average value of noise level over a particular time period ( $\mathrm{T}$ ) the $\mathrm{L}_{\text {Aeq }}$ was determined. The $\mathrm{L}_{\text {Aeq }}$ of background noise and aircraft noise was obtained by using the following relation:

$$
\mathrm{L}_{\text {Aeq }}=10 \log _{10}\left[\sum_{i=1}^{n} f_{i} 10^{0.1 L i}\right]
$$

Where $f_{i}=$ Fraction of time that the sound pressure level is in the $\mathrm{i}^{\text {th }}$ interval.

$=1(\because$ average disturbance due to aircraft is considered as $30 \mathrm{sec}$.for every data).

$\mathrm{N}=$ Total number of data observed, $\mathrm{L}_{\mathrm{i}=}$ Noise level in the $i^{\text {th }}$ sample.

Thus background noise has significant role to increase the aircraft noise. When the background noise level $\mathrm{L}_{\text {Aeq }}$ is excluded it gives the pure aircraft noise. The pure aircraft noise becomes somewhat less than the ambient noise of aircraft which can be obtained by using the following formula:

$$
L_{\text {Aeq }}=10 \log 10\left[\frac{1}{T} \int_{0}^{T} 10^{0.1 z i} d t\right]
$$

Where $\mathrm{T}=$ Total measurement time, $\mathrm{T}_{1}=$ Total time of aircraft noise during measurement time

$\mathrm{T}_{2}=$ Total time of background noise during measurement time, $\mathrm{L}_{1}=$ Average aircraft noise $\mathrm{L}_{2}=$ Average background noise

Data collected from the field were analyzed using statistical tool like standard deviation (ó), and appropriate software program Microsoft excel and origin were used. Appropriate bar diagrams were plotted to obtain diurnal variation of background noise, aircraft noise and pure aircraft noise in excel program. Furthermore contour maps were drawn with the help of origin program to illustrate the spatial variation of different types noise level $\mathrm{L}_{\text {Aeq. }}$

\section{Results and Discussion \\ Diurnal variation of noise}

The noise level $\mathrm{L}_{\text {Aeq }}$ of background noise and aircraft noise were analyzed by plotting bar diagrams for all sampling sites. Although $\mathrm{L}_{\text {Aeq }}$ of aircraft noise level 
Mohan K. Bhattarai and B.K.Sapkota/Study on Aircraft Noise.....

first increased from background noise level and reached to peak value then it again declined to background noise, aircraft noise fluctuation occurred during whole day thus standard diurnal variation pattern was not observed with that of background noise. It was found that aircraft produced noise effect for 15 second to 50 second.

\section{Spatial variation of aircraft noise}

The noise at a particular location depends upon the source nearby. Some statistics of noise level $\mathrm{L}_{\text {Aeq }}$ of background noise, and noise due to aircraft landing, aircraft take-off and their average values have been shown in the Table 1 and 2 . The $\mathrm{L}_{\text {Aeq }}$ for average background noise was maximum at Balkumari (73.2 dBA) due to high traffic movement. Further, the $\mathrm{L}_{\text {Aeq }}$ for background noise was minimum at Datidol (49.2 dBA) due to low traffic movement. The standard deviation $(\sigma)$ of $\mathrm{L}_{\mathrm{Aeq}}$ for background noise at Koteshwar was 3.54 dBA which was maximum deviation of noise level observed. The high standard deviation of noise level indicated that sources of noise were fluctuating where vehicles were the main sources of noise. The standard deviation $(\sigma)$ of $\mathrm{L}_{\text {Aeq }}$ for background noise level measured at Harisiddhi was
$0.85 \mathrm{dBA}$. Some statistical data of background noise of different sampling sites have been shown in Table 1 .

Experimental data exhibited that maximum value of $\mathrm{L}_{\text {Ae }}$ due to aircraft was $107.1 \mathrm{dBA}$ at Gothatar A, which lied on north east from the airport and same height as the airport ground. When aircrafts made turning, the vibration produced on the ground gave maximum noise level because the turning points of aircrafts lied nearby Gothatar. The standard deviation $(\sigma)$ of $\mathrm{L}_{\text {Aeq }}$ for aircraft noise was also maximum at Gothatar $\mathrm{A}(8.82 \mathrm{dBA})$ thus high noise fluctuation occurred during aircraft movemnent. The minimum value of $\mathrm{L}_{\text {Aeq }}$ due to aircraft was $63.5 \mathrm{dBA}$ at Datidol which indicated that Datidol was quite safe zone. Some statistical data of aircraft noise have been presented in Table 2. The multiple bar diagram shown in Figure 3 reflect that aircraft noise was greater than background noise, hence all the sampling sites selected were influenced by the aircraft noise. The sampling sites were classified according to the Kiely Land Use Guidance (LUG) chart. Most of them were fell on severe noise exposure class which indicated that some noise absorbing materials should be placed in the severe noise exposure zones of aircrafts.

Table. 1 Statistics of background noise for different sampling sites.

\begin{tabular}{|c|c|c|c|c|c|}
\hline S.N. & Sarmpling sites & $\left(\mathrm{L}_{\mathrm{AN}}\right)_{\text {min }}$ & $\left(\mathrm{L}_{\mathrm{AN}{ }_{1}}\right)_{\operatorname{man} \pi}$ & $\left(\mathrm{L}_{\text {AQq }}\right)_{\text {avorag }}$ & Standard deviation( $(\sigma)$ \\
\hline 1 & Koteshwar (KT) & 66.5 & 74.8 & 71.9 & 3.54 \\
\hline 2 & Gothatar A(GA) & 49.8 & 53.2 & 51.5 & 1.40 \\
\hline 3 & Nayakatti (NK) & 67.5 & 72.5 & 70.2 & 1.84 \\
\hline 4 & Jadibuti (JD) & 69.2 & 75.2 & 72.6 & 2.38 \\
\hline 5 & Irmadol A (IA) & 47.3 & 55.4 & 52.3 & 3.22 \\
\hline 6 & Balkumari (BK) & 68.5 & 75.6 & 73.2 & 2.57 \\
\hline 7 & Nayabasti (NB) & 62.1 & 68.2 & 66.3 & 2.32 \\
\hline 8 & Gothatar B (GB) & 47.2 & 53.4 & 51.2 & 2.36 \\
\hline 9 & Datidol (DD) & 46.3 & 51.1 & 49.2 & 1.96 \\
\hline 10 & Imadol B (IB) & 49.2 & 52.3 & 510 & 1.50 \\
\hline 11 & Khumaltar $(\mathrm{KH})$ & 49.2 & 52.1 & 50.8 & 1.11 \\
\hline 12 & Maharkal (MK) & 66.5 & 71.2 & 69.7 & 1.74 \\
\hline 13 & Tinchuli (TN) & 46.5 & 53.4 & 50.9 & 2.80 \\
\hline 14 & Jorpati (JP) & 62.3 & 67.2 & 65.8 & 1.90 \\
\hline 15 & Bahundhara $(\mathrm{BH})$ & 65.2 & 70.1 & 680 & 1.76 \\
\hline 16 & Harisiddhi (HA) & 51.0 & 53.4 & 52.4 & 0.85 \\
\hline 17 & Dhapakhel(DA) & 46.5 & 51.2 & 49.5 & 1.83 \\
\hline
\end{tabular}


Table 2. Statistics of aircraft noise, $\left(\mathrm{L}_{\text {Aeq }}\right)$ in dBA for different sampling sites.

\begin{tabular}{|c|c|c|c|c|c|c|}
\hline 5.N. & Sampling sites & $\left(\mathrm{L}_{\mathrm{AN}}\right)_{\text {min }}$ & $\left(\mathrm{L}_{\mathrm{An}}\right)_{\max \pi}$ & $\left(\mathrm{L}_{\mathrm{An}}\right)_{a v}$ & $\begin{array}{l}\text { Standard } \\
\text { deviation }(\sigma)\end{array}$ & $\begin{array}{l}\text { Pure aircraft } \\
\text { noise }\end{array}$ \\
\hline 1 & Koteshwar & 73.2 & 91.2 & 86.2 & 4.87 & 73.4 \\
\hline 2 & Gothatar A & 80.1 & 107.1 & 101.5 & 8.82 & 83.1 \\
\hline 3 & Nayakatti & 72.9 & 88.7 & 82.6 & 4.96 & 71.0 \\
\hline 4 & Jadibuti & 78.5 & 89.2 & 85.7 & 3.24 & 73.5 \\
\hline 5 & Imadol A & 77.3 & 85.2 & 81.2 & 2.49 & 62.5 \\
\hline 6 & Balkumari & 75.6 & 85.6 & 80.5 & 3.23 & 73.3 \\
\hline 7 & Navabasti & 747 & 89.9 & 837 & 3.99 & 69.3 \\
\hline 8 & Gothatar B & 87.2 & 100.3 & 97.4 & 4.56 & 79.0 \\
\hline 9 & Datidol & 61.4 & 67.1 & 63.5 & 1.42 & 50.5 \\
\hline 10 & Imadol B & 63.6 & 77.1 & 81.4 & 3.12 & 63.2 \\
\hline 11 & Khumaltar & 64.2 & 72.5 & 69.5 & 2.61 & 53.6 \\
\hline 12 & Mahankal & 70.1 & 75.2 & 72.8 & 6.05 & 69.7 \\
\hline 13 & Tinchuli & 63.3 & 77.1 & 72.4 & 4.37 & 55.7 \\
\hline 14 & Jorpati & 71.5 & 83.5 & 79.7 & 4.02 & 67.3 \\
\hline 15 & Bahundhar & 74.7 & 85.5 & 81.3 & 3.50 & 69.1 \\
\hline 16 & Harisiddhi & 59.2 & 67.3 & 65.1 & 3.11 & 53.3 \\
\hline 17 & Dhapakhel & 64.2 & 81.3 & 75.2 & 4.19 & 57 \\
\hline
\end{tabular}

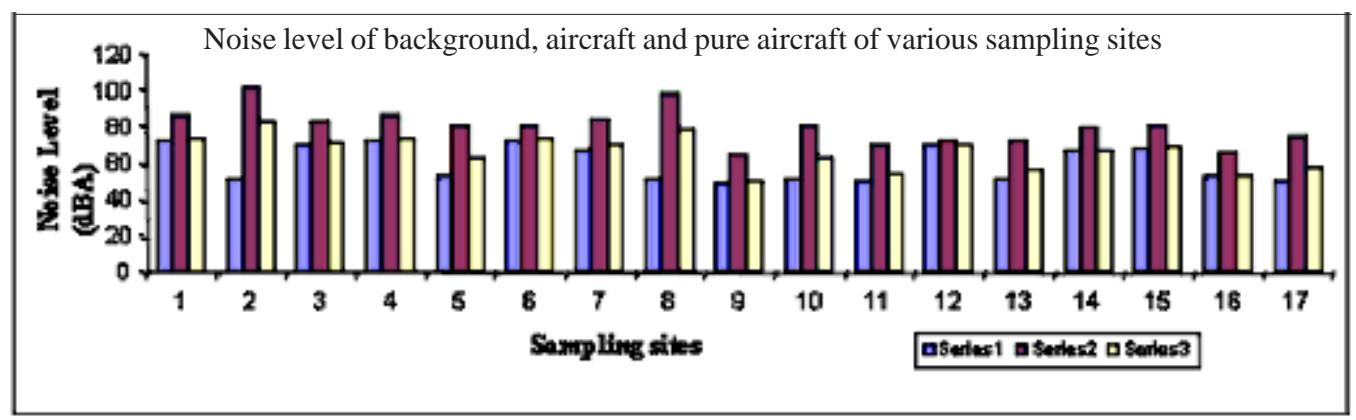

Fig.3. Multiple bar diagram showing background noise, aircraft noise and pure aircraft noise

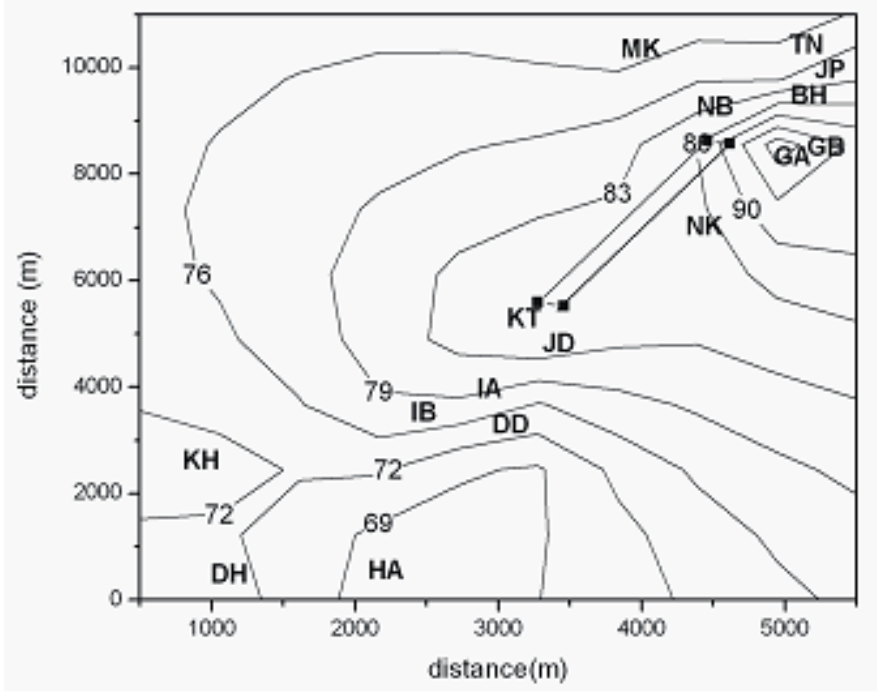

Fig. 1. Contour map of average aircraft noise at Tribhuvan International Airport 
Mohan K. Bhattarai and B.K.Sapkota/Study on Aircraft Noise.....

Spatial variations pattern of $\mathrm{L}_{\text {Aeq }}$ of average aircraft noise of different sampling sites are plotted in contour map shown in the Fig. 1. The numbers shown in each contour indicated that noise level exceeded within that contour. Study of contour map showed that north east side of TIA was mostly affected by aircraft noise. Thus,
Gothatar is the noisiest among all the sampling sites chosen. Hence national noise level standard has to be formulated and implementation of noise control measures and public awareness about the adverse effect of noise should be created.

Table. 3 Distribution of sampling sites according to Kiely LUG chart

\begin{tabular}{|c|c|c|c|c|c|c|c|}
\hline LUG & $\begin{array}{l}\text { Noise exposure } \\
\text { class }\end{array}$ & $\begin{array}{l}\text { Sampling } \\
\text { sites }\end{array}$ & $\left(\mathrm{L}_{\mathrm{AN}_{1}}\right)_{\text {barliner }}$ & $\begin{array}{l}\text { Sampling } \\
\text { sites }\end{array}$ & $\left(\mathrm{L}_{\mathrm{A} \mathrm{q}_{\mathrm{Q}}}\right)_{\mathrm{tl} \mathrm{l}-\mathrm{off}}$ & $\begin{array}{l}\text { Sarnpling } \\
\text { sites }\end{array}$ & $\left(\mathrm{L}_{\mathrm{AN}-\mathrm{l}}\right)_{\mathrm{av}}$ \\
\hline$\overline{\mathrm{A}}$ & Minimum (0-55) & & & & & & \\
\hline $\mathrm{B}$ & $\begin{array}{l}\text { Moderate (55- } \\
65)\end{array}$ & $\mathrm{DD}$ & 62.6 & $\begin{array}{l}\mathrm{DD} \\
\mathrm{HA}\end{array}$ & $\begin{array}{l}64.3 \\
63.5\end{array}$ & $\mathrm{DD}$ & 63.5 \\
\hline $\mathrm{C}$ & Significant & IB & 71.2 & & & & \\
\hline & $(65-75)$ & $\mathrm{KH}$ & 70.5 & $\mathrm{KH}$ & 68.3 & $\mathrm{KH}$ & 69.5 \\
\hline & & $\mathrm{MK}$ & 72.6 & MK & 73.1 & MK & 72.8 \\
\hline & & $\mathrm{TH}$ & 73.1 & TH & 71.7 & $\mathrm{TH}$ & 72.4 \\
\hline & & $\mathrm{HA}$ & 66.4 & $\mathrm{DH}$ & 73.7 & $\mathrm{HA}$ & 65.1 \\
\hline $\mathrm{D}$ & Severe & & & IB & 84.2 & IB & 81.4 \\
\hline & $(\geq 75)$ & $\mathrm{KT}$ & 84.7 & $\mathrm{KT}$ & 87.7 & $\mathrm{KT}$ & 86.2 \\
\hline & & $\mathrm{GA}$ & 104 & $\mathrm{GA}$ & 95.4 & $\mathrm{GA}$ & 101.5 \\
\hline & & MK & 85 & NK & 76.9 & NK & 82.6 \\
\hline & & $\mathrm{NB}$ & 79.9 & NB & 85.8 & NB & 83.7 \\
\hline & & $\mathrm{JD}$ & 85.6 & JD & 85.8 & $\mathrm{JD}$ & 85.7 \\
\hline & & IA & 80.5 & IA & 81.8 & IA & 81.2 \\
\hline & & $\mathrm{BK}$ & 81.8 & $\mathrm{BK}$ & 78.7 & $\mathrm{BK}$ & 80.5 \\
\hline & & GB & 99.8 & $\mathrm{~GB}$ & 92 & $\mathrm{~GB}$ & 97.4 \\
\hline & & $J P$ & 79.5 & JP & 79.5 & $\mathrm{JP}$ & 79.5 \\
\hline & & $\mathrm{BH}$ & 78.9 & $\mathrm{BH}$ & 82.9 & $\mathrm{BH}$ & 81.3 \\
\hline & & $\mathrm{DH}$ & 76.4 & & & $\mathrm{DH}$ & 75.2 \\
\hline
\end{tabular}

\section{Acknowledgements}

Authors would like to express their gratitude to Prof. L.N. Jha for his profound support for this study. Acknowledgments are highly accorded to K.K. Chhetry, CAAN and Prof B.P. Pokharel, for their valuable suggestions and information. We are thankful to NAST staff Tista Prasain and Sashi. Thapa, for their kind co-operation and providing noise meter.

\section{References}

Berglund, B. and T. Lindvall. 1995. Community noise, center for sensory research Stockholm, Sweden.

Biswas, D. 2002. Noise pollution around Netaji Subhash Chandra Bose International airport Kolkata, A case study submitted to Central Pollution Control Board, Ministry of Environment \& Forests, Govt. of India, New Delhi.

CAAN. 2004, 2005 and 2007. Souvenir. Civil Aviation Authority Nepal, Babarmahal, Kathmandu, Nepal.

Chhetry, K.K. 2001. Impact study of TIA on adjoining settlement area, M.Sc. dissertation, SchEM, Pokhara University, Kathmandu, Nepal.
Garg, M.R. and V. K. Bansal. 1995. Environmental pollution and protection. New Delhi, Deep and Deep Publication.

Kiely, G.1998. Environmental Engineering, NewYork., Mc Grew-Hill.

Manandhar, M.S., N.G. Ranjitkar, P.K. Pradhan and N.R. Khanal. 1987. A study on health hazard in Kathmandu city. Report Submitted to National Committee for Man and the Biosphere, Kathmandu, Nepal.

Miyoshi, Y. 1987. Pollution control in selected industries, ISC, Balaju, Kathmandu, Nepal.

NECG. 1990. Industrial pollution survey in Nepal, Nepal Environmental Conservation Group with NPC/IUCN.

Nixon, J.C. and A. Glorig.1961. Noise induced permanent threshold shift at $2000 \mathrm{cps}$ and $4000 \mathrm{cps}$. The Journal of Acoustical Society of America 33(7) 904-908.

Sapkota, B.K. 2000. Noise standard and monitoring mechanism for major cities of Nepal. Technical Report, Ministry of Population and Environment, Singh Durbar, Kathmandu, Nepal. 
Sapkota, B.K. 2004. Fundamental of noise pollution. Department of Physics, Institute of Engineering, Pulchowk, Lalitpur, Nepal.

Shrestha, C.B. G.B. Shrestha. 1985. Survey of noise level in Kathmandu city. Submitted to Nepal National Committee for Man and Biosphere, Kathmandu, Nepal.

Tarnopolsky, A., D.J. Hand, S.M. Barker, and L.M. Jenkins. 1980. Aircraft noise, annoyance and mental health. Rockvile, ML ASHA Reports 10, pp. 588-594.
Tuladhar, S.M., R.C. Shrestha, D.S. Rawal, and T.M. Pradhananga. 1999. Indoor noise level monitoring in different industries of Kathmandu valley. Nepal Journal of Science and Technology Journal 6: 315-327.

WHO. 1980. Sound noise and environmental health criteria, Document No. 12, World Health Organisation, Geneva, Switzerland.

WHO. 2000. Guidelines for community noise. World Health Organization, Geneva, Switzerland. 